\title{
Low temperature vibrational spectroscopy. I. Hexachlorotellurates
}

\author{
Berg, Rolf W.; Poulsen, Finn Willy; Bjerrum, Niels
}

Published in:

Journal of Chemical Physics

Link to article, DOI:

$10.1063 / 1.435139$

Publication date:

1977

Document Version

Publisher's PDF, also known as Version of record

Link back to DTU Orbit

Citation (APA):

Berg, R. W., Poulsen, F. W., \& Bjerrum, N. (1977). Low temperature vibrational spectroscopy. I.

Hexachlorotellurates. Journal of Chemical Physics, 67(5), 1829-1837. https://doi.org/10.1063/1.435139

\section{General rights}

Copyright and moral rights for the publications made accessible in the public portal are retained by the authors and/or other copyright owners and it is a condition of accessing publications that users recognise and abide by the legal requirements associated with these rights.

- Users may download and print one copy of any publication from the public portal for the purpose of private study or research.

- You may not further distribute the material or use it for any profit-making activity or commercial gain

- You may freely distribute the URL identifying the publication in the public portal

If you believe that this document breaches copyright please contact us providing details, and we will remove access to the work immediately and investigate your claim. 


\title{
Low temperature vibrational spectroscopy. I. Hexachlorotellurates
}

\author{
Rolf W. Berg, " Finn W. Poulsen, and Niels J. Bjerrum \\ Chemistry Department A, The Technical University of Denmark, Building 207, DK-2800 Lyngby, Denmark \\ (Received 3 November 1976) \\ Far infrared and Raman spectra of six hexachlorotellurate (IV) salts have been obtained at $\sim 100 \mathrm{~K}$ for \\ the first time. In the rubidium, cesium, ammonium, and tetramethylammonium salts the Raman active $T_{28}$ \\ cation lattice translatory mode was found. In the monoclinic $\mathrm{K}_{2}\left[\mathrm{TeCl}_{6}\right]$ a number of low frequency lattice \\ modes were observed and interpreted in terms of a phase transition near $165 \mathrm{~K}$, similar to transitions in \\ other $\mathbf{K}_{2}\left[\mathbf{M X}_{6}\right]$ salts. The cubic tetramethylammonium hexachlorotellurate salt undergoes a phase transition \\ of supposed first order at a temperature near $110 \mathrm{~K}$, corresponding to transitions known in analogous \\ uranium and tin compounds. Possible reasons for the transitions are discussed. In the low temperature \\ phases the $v_{4}$ and $v_{6}$ bendings of $\left[\mathrm{TeCl}_{6}\right]^{2-}$ have been identified with bands near $\sim 130$ and $\sim 110 \mathrm{~cm}^{-1}$. No \\ evidence seemed to favor any stereochemical distortion due to the lone pair of electrons present in \\ hexachlorotellurates.
}

\section{INTRODUCTION}

In 1957, Gillespie and $\mathrm{Nyholm}^{1}$ developed the valence shell electron-pair repulsion theory, according to which the lone pair of electrons present in, for example, the hexachlorotellurate (IV) complex anion should be stereochemically active and distort the coordination polyhedron from being regular octahedral (Gillespie effect). However, several $x$-ray crystal structures of $\mathrm{A}_{2}\left[\mathrm{TeX}_{6}\right]$ salts (A being an alkali metal and $\mathrm{X}$ a halogen) have been determined, ${ }^{2-5}$ and in all cases reported so far the coordination was found to be regular octahedral at room temperature. For the hexachlorotellurate series of compounds, there is further evidence for the absence of any Gillespie effect: (i) the crystallographic equivalence of the six chlorine atoms of $\left(\mathrm{NH}_{4}\right)_{2}\left[\mathrm{TeCl}_{6}\right]$ down to liquid-nitrogen temperature shown by nuclear quadrupole resonance experiments ${ }^{6}$; (ii) the absence of any quadrupole splitting in ${ }^{125} \mathrm{Te}$ Mössbauer spectra ${ }^{7}$ of $\mathrm{Rb}_{2}\left[\mathrm{TeCl}_{6}\right], \mathrm{Cs}_{2}\left[\mathrm{TeCl}_{6}\right]$, and $\left[\mathrm{NH}_{4}\right]_{2}\left[\mathrm{TeCl}_{6}\right]$ cooled to $80 \mathrm{~K}$.

The room temperature vibrational spectra of $\left[\mathrm{TeCl}_{0}\right]^{2-}$ salts have been much studied over the past decade, ${ }^{0-20}$ partly owing to the considerable interest in the stereochemical properties of lone-pair compounds. Even oriented single crystal Raman spectra of $\left(\mathrm{NH}_{4}\right)_{2}\left[\mathrm{TeCl}_{6}\right]^{13}$ and high pressure infrared spectra of a series of hexahalogenotellurate (IV) salts ${ }^{17,20}$ have been obtained. No low temperature vibrational results seem to have been reported for the $\mathrm{A}_{2}\left[\mathrm{TeX}_{6}\right]$ series, except for some bromides in the infrared. ${ }^{20}$

The present work was undertaken because it was felt that combined infrared and Raman spectroscopy at low temperature performed on a series of hexachlorotellurate salts could make a valuable contribution to the understanding of the properties of hexachlorotellurate complexes both in solid and molten salts. ${ }^{21}$ These salts are known to have rather peculiar vibrational spectra. Generally, the Raman active $\nu_{1}\left(A_{1 g}\right)$ stretching band (Herzberg notation) is relatively weak and the infrared active $\nu_{3}\left(T_{1 u}\right)$ stretching and $\nu_{4}\left(T_{1 u}\right)$ bending bands are exceptionally strong and broad, and vanishing weak, respectively. These features of the $\left[\mathrm{TeCl}_{6}\right]^{2-}$ salts differ from those seen in most spectra of isostructural $\mathrm{A}_{2}\left[\mathrm{MX}_{6}\right]$ salts, as discussed in several papers, ${ }^{8-21}$ and various theories explaining this (including the presence of a dynamic Jahn-Teller distortion $)^{14}$ have been proposed. $14,17,18,20$

Among the compounds investigated, $\mathrm{K}_{2}\left[\mathrm{TeCl}_{6}\right]$ is known to have only a pseudocubic structure, a fact which has been attributed to the small size of the $\mathrm{K}^{*}$ ion. It was found of interest to see what effect this unique structure has on the spectra during cooling. The tetramethylammonium salt was included for completeness and because low-temperature phase changes have recently been reported for similar $\mathrm{U}, \mathrm{Sn}$, and $\mathrm{Zr}$ compound $5^{22,23}$ and may therefore be expected to occur in the tellurium salt as well.

In this paper we report the low temperature $(\sim 100 \mathrm{~K})$ powder spectra of six hexachlorotellurates for the first time. For the $\mathrm{Rb}, \mathrm{Cs}$, and $\mathrm{NH}_{4}$ salts, which retain their cubic structure down to $80 \mathrm{~K}$, only minor spectral changes are seen. The same behavior is found for the thallium salt. For the $\mathrm{K}$ and $\left(\mathrm{CH}_{3}\right)_{4} \mathrm{~N}$ (= tetramethylammonium) salts, remarkable changes with temperature are seen, and possible explanations for their behaviors are discussed. The results obtained add to the prevailing picture (e.g., Ref. 8, 10, and 18) of regular octahedral coordination of chlorine around tellurium, i. e., no detectable Gillespie effect.

\section{STRUCTURES AND SELECTION RULES}

\section{A. Cubic compounds}

The salts $\mathrm{A}_{2}\left[\mathrm{TeCl}_{6}\right]$ (with $\mathrm{A}=\mathrm{Cs}, \mathrm{Rb}, \mathrm{Tl}$, and $\mathrm{NH}_{4}$ ) are known ${ }^{2-5}$ to crystallize at ambient temperature in the $\mathrm{K}_{2}\left[\mathrm{PtCl}_{8}\right]$-type cubic face-centered antifluorite lattice, belonging to the space group $O_{h}^{5}(F m 3 m$, No. 225), having one formula in the primitive cell. The lattice is illustrated in Fig. 1. Structural data for $\left(\left(\mathrm{CH}_{3}\right)_{4} \mathrm{~N}\right)_{2}\left[\mathrm{TeCl}_{6}\right]$ are not available, but it can be assumed that this compound also adopts this type of lattice at room temperature.

For a monatomic cation, $\mathrm{A}=\mathrm{Cs}, \mathrm{Rb}$, and $\mathrm{Tl}$, the factor group expectations based on the wavevector $k \simeq 0$ approximation have been derived previously, and Table I contains a summary of the results. This table also 


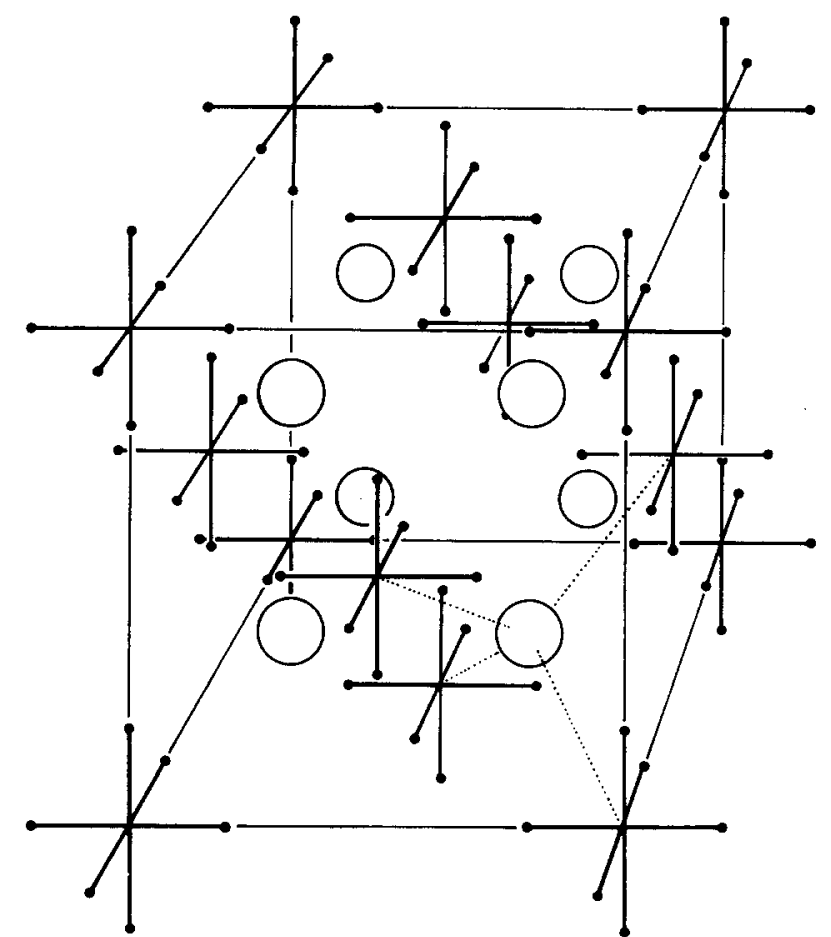

FIG. 1. Cubic unit cell of $\mathrm{A}_{2}\left[\mathrm{TeCl}_{6}\right]$ salts having the $\mathrm{K}_{2}\left[\mathrm{PtCl}_{6}\right]$ type structure.

includes the more complicated cases where $\mathrm{A}$ is ammonium or tetramethylammonium. Within the $O_{h}^{5}$ space group symmetry such tetrahedral ions can be accomodated at the cation sites $c$ (Wyckoff notation) in two different ways, parallel or perpendicular, ${ }^{22}$ depending on whether the cation skeletal bonds point toward nearest tellurium atoms or not (cf. Fig. 1). The selection rules predicted are unaffected by the choice actually made by Nature, provided the crystal is ordered.

The cation internal modes have been omitted from Table I for the following reasons: (i) Bond stretchings and angle deformations involving hydrogen atoms occur at high frequencies compared to the spectral range of interest here, and the same is true for $\mathrm{C}-\mathrm{N}$ stretchings; (ii) Methyl group torsions transform ${ }^{22}$ as $A_{2 g}+T_{1_{g}}$

TABLE I. Unit cell group analysis ${ }^{2}$ of $\mathrm{A}_{2}\left[\mathrm{TeCl}_{6}\right]$ salts of space group $O_{h}^{5}$ ( $F m 3 m$, No. 225). The primitive cell contains one formula with Te on Wyckoff site $a\left(O_{h}\right.$ symmetry), A on site $c$ ( $T_{d}$ symmetry), and $\mathrm{Cl}$ on site $e\left(C_{4 v}\right.$ symmetry). $\mathrm{A}=\mathrm{Rb}, \mathrm{Cs}$, $\mathrm{NH}_{4}$, or $\left(\mathrm{CH}_{3}\right)_{4} \mathrm{~N}$.

\begin{tabular}{|c|c|c|c|c|c|c|}
\hline $\begin{array}{l}O_{h} \\
\text { symmetry }\end{array}$ & $T_{A}$ & $T$ & $R^{-}$ & $R^{+}$ & $N_{i}$ & $\begin{array}{l}\text { Activity } \\
\text { in }\end{array}$ \\
\hline$\overline{A_{1 x^{\prime}}\left(\Gamma^{1+}\right)}$ & & & & & $\begin{array}{l}1\left(v_{1}, \text { str. }\right) \\
1\left(v_{n}, \text { str. }\right)\end{array}$ & $\begin{array}{l}\text { Raman } \\
\text { Raman }\end{array}$ \\
\hline$T_{1 g}\left(\Gamma^{1 \eta}\right)$ & & & $1\left(v_{L 1}\right)$ & $1\left(\nu_{L \theta}\right)$ & & \\
\hline$T_{2 g}\left(\Gamma^{f+}\right)$ & & $1\left(v_{L}\right)$ & & & $I\left(\nu_{5}\right.$, bend. $)$ & Raman \\
\hline$T_{1 \mu}\left(\Gamma^{4-}\right)$ & 1 & $1\left(v_{L 3}\right)$ & & & $2\left(v_{3}\right.$, str. $+v_{4}$, bend. $)$ & ir \\
\hline$T_{2 u}\left(\Gamma^{s_{i}-}\right)$ & & & & $1\left(v_{L 5}\right)$ & $1\left(v_{f}\right.$, bend. $)$ & \\
\hline
\end{tabular}

${ }^{2}$ Internal modes of $A$ [for $\mathrm{NH}_{4}$ and $\left(\mathrm{CH}_{3}\right)_{4} \mathrm{~N}$ ] have been omitted, see text. $T_{A}=$ inactive acoustic, $T=$ optic-branch translatory, and $R^{-}=$rotatory modes of $\left[\mathrm{TeCl}_{6}\right], R^{+}=$rotatory modes of $\mathrm{NH}_{4}$ or $\left(\mathrm{CH}_{3}\right)_{4} \mathrm{~N}$ (where applicable), and $N_{i}=$ internal modes of $\left[\mathrm{TeCl}_{6}\right]$. The irreducible representations given in parentheses are solid state notation used in Refs. 28 and 29.
$+A_{1 u}+T_{2 u}$ and thus are all inactive under $O_{h}$ (their frequencies are expected near $\left.300 \mathrm{~cm}^{-1}\right)^{24}$; (iii) Tetramethylammonium skeletal bendings of symmetry types $E_{g}+E_{u}$ (from the $E$-type mode under $T_{d}$ symmetry of frequency near $\left.368 \mathrm{~cm}^{-1}\right)^{22,25,26}$ and $T_{2 g}+T_{1 u}$ (from the $T_{2}$-type mode under $T_{d}$ occurring near $455 \mathrm{~cm}^{-1}$ ) may be observed ( $E_{g}$ and $T_{2 g}$ in Raman and $T_{1 u}$ in infrared), but the frequencies are high enough to permit these modes to be clearly distinguished from the $\left[\mathrm{TeCl}_{6}\right]^{2-}$ modes (ignoring the possibility of anion-cation couplings). Cation librations $T_{1_{g}}+T_{2 u}$ are inactive (Table I), and thus no complications due to the internal molecular structure of the $\mathrm{NH}_{4}$ or $\left(\mathrm{CH}_{3}\right)_{4} \mathrm{~N}$ ions are expected in the spectral range $0-350 \mathrm{~cm}^{-1}$. Therefore, all the cubic compounds should have similar spectra; $i_{0} e_{0}$, showing four bands in $\operatorname{Raman}\left(\nu_{1}, \nu_{2}, \nu_{5}\right.$, and $\left.\nu_{L 2}\right)$ and three bands in far ir $\left(\nu_{3}, \nu_{4}\right.$, and $\left.\nu_{L 3}\right)$.

\section{B. Monoclinic $\mathrm{K}_{2}\left[\mathrm{TeCl}_{6}\right]$}

The structure of this salt is incompletely solved, ${ }^{2}$ but enough is known to allow a depiction of its essential structure (Fig. 2)。 This salt crystallizes much like the $\mathrm{K}_{2}\left[\mathrm{PtCl}_{6}\right]$ salt and is very nearly cubic in its parameters $\left(C_{2 h}^{3}, \beta \simeq 90^{\circ}, a \sqrt{2} \simeq b \sqrt{2} \simeq c\right)^{2}$. Enough is al-

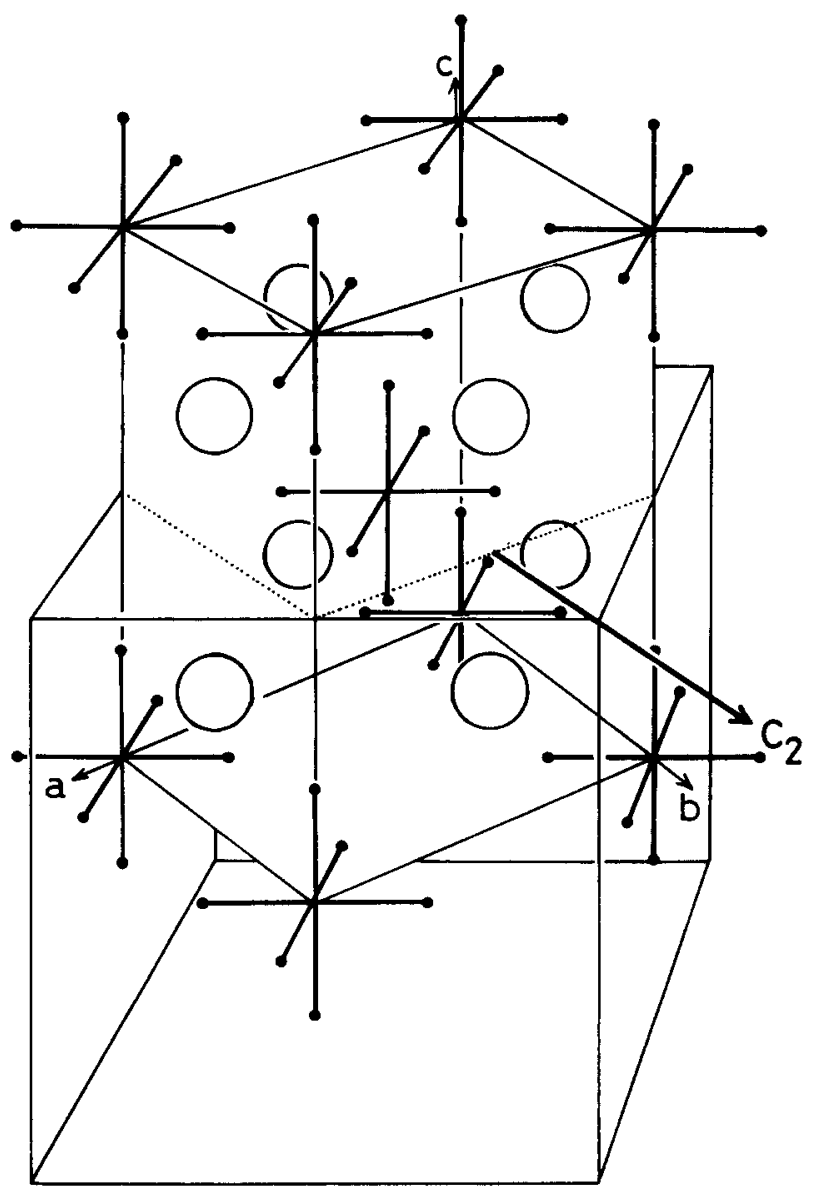

FIG. 2. The structure of $\mathrm{K}_{2}\left[\mathrm{TeCl}_{6}\right]$ as determined by Engel, ${ }^{2}$ showing an unconventional centered monoclinic unit cell (of space group $\left.C_{2 h}^{3}(\mathrm{C2} / \mathrm{m})\right)$ which is most convenient when comparing with the $\mathrm{K}_{2}\left[\mathrm{PtCl}_{6}\right]$ type structure. Note the direction of the twofold symmetry axis. The positions of atoms except Te are incompletely known, cf. Table II. 
TABLE $\Pi$. Structural data ${ }^{2}$ and unit cell group analysis ${ }^{2}$ of $\mathrm{K}_{2}\left[\mathrm{TeCl}_{6}\right]$ having space group $C_{2 h}^{3}(\mathrm{C2} / \mathrm{m}$, No. 12$)$. The primitive cell contains one formula with Te on Wyckoff site $a\left(C_{2 h}\right.$ symmetry), $\mathrm{K}$ on site $i$ ( $C_{s}$ symmetry), and $\mathrm{Cl}$ on sites $i$ and $j$ ( $C_{s}$ and $C_{1}$ symmetries). With $a=7.17 \AA, b=7.17 \AA, c=10.14$ $\AA$, and $\beta \approx 90^{\circ}$, the fractional coordinates are $\mathrm{Te}(0,0,0)$; $\mathrm{K}\left(\sim \frac{1}{2}, 0, \sim \frac{1}{4}\right), \mathrm{Cl}_{i}\left(\sim 0,0, \sim \frac{1}{4}\right), \mathrm{Cl}_{f}\left(\sim \frac{1}{4}, \frac{1}{4}, 0\right)$.

\begin{tabular}{llllll}
\hline \hline$C_{2 h}$ & & & & \\
symmetry & $T_{A}$ & $T$ & $R^{-}$ & $N_{i}{ }^{\mathrm{b}}$ & Activity \\
\hline$A_{z}$ & & $2\left(\nu_{L 2}\right)$ & $1\left(\nu_{L 1}\right)$ & $4\left(\nu_{1}+\nu_{2}+2 \nu_{5}\right)$ & Raman \\
$B_{z}$ & & $1\left(\nu_{L 2}\right)$ & $2\left(\nu_{L 1}\right)$ & $2\left(\nu_{2}, \nu_{5}\right)$ & Raman \\
$A_{u}$ & 1 & $1\left(\nu_{L 3}\right)$ & & $4\left(\nu_{3}, v_{4}, 2 \nu_{6}\right)$ & ir \\
$B_{u}$ & 2 & $2\left(\nu_{L 3}\right)$ & & $5\left(2 \nu_{3}, 2 \nu_{4}, \nu_{6}\right)$ & ir \\
\hline \hline
\end{tabular}

${ }^{2}$ For explanation see Table I. For the correlation of the internal modes it is essential to note that one of the six interbond $\mathrm{C}_{2}$ axes of $O_{h}$ is retained as the $\mathrm{C}_{2}$ axis in $C_{2 h}$. The correlation scheme is then $A_{1 \xi} \rightarrow A_{g}, E_{g} \rightarrow A_{g}+B_{g}, T_{2 g} \rightarrow 2 A_{g}+B_{g}, T_{1 u} \rightarrow A_{u}$ $+2 B_{u}, T_{2 u} \rightarrow 2 A_{u}+B_{u}$.

${ }^{\mathrm{b}}$ The notation of frequencies $\left(\nu_{1}-\nu_{6}\right)$ refers to $O_{h}$ symmetry, see Table I.

so known to allow the factor group analysis to be derived (Table II). Let us consider why $\mathrm{K}_{2}\left[\mathrm{TeCl}_{6}\right]$ is monoclinic. Engel $^{2}$ al ready attributed this to the small size of $\mathrm{K}^{+}$. It is instructive to compare the situation with that of $\mathrm{K}_{2}\left[\mathrm{TeBr}_{6}\right]$, the structure of which has been accurately determined. ${ }^{4}$ It is also monoclinic, though of another space group, $C_{2 n}^{5}$. $\left(\mathrm{NH}_{4}\right)_{2}\left[\mathrm{TeBr}_{6}\right]$ and $\mathrm{Cs}_{2}\left[\mathrm{TeBr}_{6}\right]$, on the other hand, have the cubic structure ${ }^{27}$ like the chlorides. The $\mathrm{K}_{2}\left[\mathrm{TeBr}_{6}\right]$ structure can be considered as a cubic $\mathrm{K}_{2}\left[\mathrm{PtCl}_{6}\right]$ lattice in which distortions have occurred, reducing the effective size of the cation cavities.

The distortions in $\mathrm{K}_{2}\left[\mathrm{TeBr}_{6}\right]$ consist of the following: (i) an alternate twisting of neighboring regular octahedra about the $c$ axis by $12^{\circ}$, and (ii) a twisting of all octahedra about the monoclinic $b$ axis [cubic(110)] by $9^{\circ}$, followed by (iii) displacements of $\mathrm{K}^{+}$ions and adjustments of axial lengths and angles, leaving a structure of space group $C_{2 n}^{5}\left(P 2_{1} / n\right.$, No. 14, $\left.Z=2\right)$. For $\mathrm{K}_{2}\left[\mathrm{ReCl}_{B}\right]$ and $\mathrm{K}_{2}\left[\mathrm{SnCl}_{6}\right]$, similar twistings of type (i) have been found to occur without twistings of type (ii), making the structures of these salts noncubic. ${ }^{28,29}$ Other examples of distortions probably explainable along these lines are given in Ref. 4. With these results in mind, it is tempting to suggest that $\mathrm{K}_{2}\left[\mathrm{TeCl}_{6}\right]$ is monoclinic $C_{2 h}^{3}$ due to small rotations of the $\left[\mathrm{TeCl}_{6}\right]^{2-}$ octahedra around the [110] twofold axis in its hypothetical $O_{h}^{5}$ lattice. This picture accounts for the structural data ${ }^{2}$ : (i) the space group becomes $C_{2 h}^{3}$ \{retaining the (110) mirror plane, the [110] twofold axis, and the inversion symmetry\}; and (ii) the approximate atomic positions (Table II). As we shall see later, it also accounts for the spectral observations at room temperature but not at low temperature.

The vibrational consequences of the structure just described are dependent upon the magnitude of the rotation of $\left[\mathrm{TeCl}_{8}\right]^{2-}$. In the limit of a vanishingly small angle, the selection rules are as given for the cubic structure (Table I). On the other hand, for an appreciable rotation the results given in Table II apply.
Assuming a maximum of splitting of the mode frequencies, it is seen that a total of 12 modes should be observed in the Raman spectrum-one $\nu_{1}$, a doublet of $\nu_{2}$, and a triplet of $\nu_{5}$ (all internal modes in $\left[\mathrm{TeCl}_{6}\right]^{2-}$ ); further, a triplet of gerade translatory and a triplet of rotatory modes. The infrared spectrum should contain 12 modes as well, nine of which are $\left[\mathrm{TeCl}_{6}\right]^{2-}$ internals (three triplets of $\nu_{3}, \nu_{4}$, and $\nu_{6}$ ) and three ungerade translatory modes. Qualitative mode diagrams for the internal modes of $\left[\mathrm{TeCl}_{6}\right]^{2-}$ in the $C_{2 h}$ symmetry are given in Fig. 3, which has been derived by applying projection operators to a basis set of all changes in distances and angles and eliminating redundant modes. The externals (not shown) are as follows: one $A_{8}\left[\mathrm{TeCl}_{6}\right]^{2-}$ rotation around the $C_{2}$ axis and two $B_{R}$ rotations around axes perpendicular to this, further translations of the anion lattice against the cation lattice, $A_{u}$ along $C_{2}$ and $2 B_{u}$ perpendicular to $C_{2}$, and finally gerade translatory movements in the cation sublattice, $B_{g}$ along and $2 A_{g}$ perpendicular to $C_{2}$, the overall translational acoustic modes not being active in ir and Raman spectra.

It should be noted that the predictions in Tables I and II differ (apart from the static splittings due to the monoclinic crystal field) in that the silent rotatory $\left(\nu_{L 1}\right)$ and bending $\left(\nu_{6}\right)$ modes of $O_{h}^{5}$ become, respectively, Raman and ir allowed in $C_{2 h}^{3}$. Finally, although the group theory shows that the triply degenerate modes of the cubic cell with split into $A$ and $B$ nondegenerate modes on reducing the symmetry to $C_{2 h}^{3}$, it does not predict the magnitude or direction of these splittings.

\section{EXPERIMENTAL}

An aqueous solution of $\mathrm{ACl}\left[\mathrm{A}=\mathrm{K}, \mathrm{Rb}, \mathrm{Cs}, \mathrm{NH}_{4}\right.$, or $\left.\left(\mathrm{CH}_{3}\right)_{4} \mathrm{~N}\right]$ was added to a solution of $\mathrm{TeCl}_{4}{ }^{21}$ in hydrochloric acid, and the fine precipitate obtained was isolated, washed with hydrochloric acid, and dried in vacuum over silica gel. The thallium salt was prepared by melting together $\mathrm{TeCl}_{4}+2 \mathrm{TlCl}$ in a silica ampoule. The subsequent sampling operations were done in a dry atmosphere.

\section{The powders were mixed with polyethylene and}

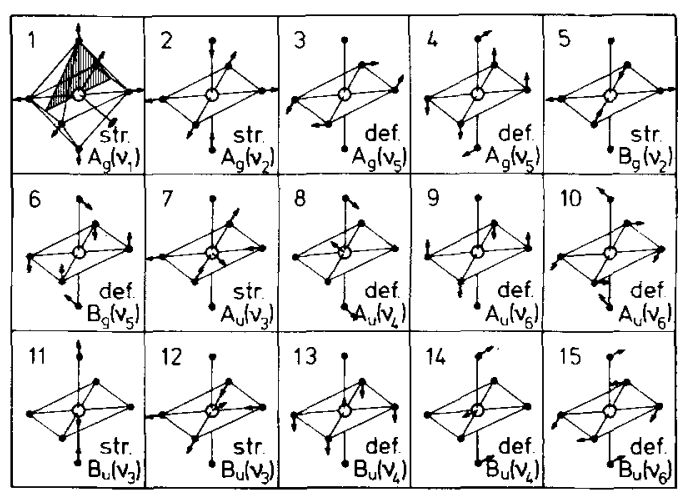

FIG. 3. Qualitative diagrams showing the 15 anion internal modes in $\mathrm{K}_{2}\left[\mathrm{TeCl}_{6}\right]$. In the first diagram the symmetry elements are indicated. The modes are classified as TeCl stretching or bending, and their $C_{2 h}$ symmetry types and $O_{h}$ origin are given. 
TABLE III. Assignments and frequencies $\left(\mathrm{cm}^{-1}\right)$ observed for $\mathrm{A}_{2}\left[\mathrm{TeCl}_{6}\right]$. Underlined figures refer to $\sim 100 \mathrm{~K}$; in $\left(\mathrm{CH}_{3}\right)_{4} \mathrm{~N}$ to the low temperature phase. ${ }^{2}$

\begin{tabular}{|c|c|c|c|c|c|c|c|}
\hline & $A=$ & $\mathrm{Rb}$ & $\mathrm{Cs}$ & $T$ & $\mathrm{NH}_{4}$ & $\mathrm{k}$ & $\left(\mathrm{CH}_{3}\right)_{4} \mathrm{~N}$ \\
\hline \multirow{9}{*}{ 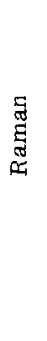 } & $2 v_{3} ?$ & & & & & 468.475 & \\
\hline & $?$ & & & & & & 301 \\
\hline & $v_{t}($ TeClstr. $)$ & $298, \underline{302} \mathrm{~s}$ & $290, \underline{292 \mathrm{~s}}$ & $301,303 \mathrm{~s}$ & $300.305 \mathrm{~s}$ & 297.294 & 281,284 \\
\hline & $v_{2}(\mathrm{TeCl}$ str. $)$ & $250,252 \mathrm{~m}$ & $248, \overline{248} \mathrm{~m}$ & $257, \overline{257} \mathrm{~m}$ & $248, \overline{252} \mathrm{~s}$ & $251, \overline{251}$ & $242, \underline{244}$ \\
\hline & $\nu_{5}(\mathrm{TeCl}$ bend. $)$ & $140, \overline{141} \mathrm{vs}$ & $141, \overline{140}$ vs & $132, \overline{134}$ vs & $142 . \overline{149} \mathrm{~s}$ & $142, \overline{149}, \underline{144}, \underline{137}$ & $136, \overline{143}, 136$ \\
\hline & $v_{L 2}$ cation & - & & & & $109 . \underline{110}$ & \\
\hline & translation & $52, \underline{54} \mathrm{vw}$ & $50, \underline{51} \mathrm{vw}$ & & $104 \mathrm{rw}$ & $70, \frac{101}{76}, \frac{93}{72}, 68$ & $64, \underline{74}, \underline{62}$ \\
\hline & $\nu_{L 1}$ anion & & & & & $59 . \overline{60}--$ & \\
\hline & librations & & & & & $\begin{array}{l}48, \overline{47}, 43 \\
36, \overline{38}\end{array}$ & \\
\hline \multirow{6}{*}{ 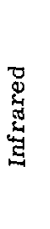 } & $\nu_{4}+\nu_{5} ?$ & & & & & $312, \underline{312}$ & \\
\hline & $?$ & & & & & & $290,293,284$ \\
\hline & $\nu_{3}$ (TeCl str.) & $\sim 250, \sim \underline{260} \mathrm{vsbr}$ & $\sim 265, \sim 260 \mathrm{vsbr}$ & $\sim 240, \sim 250 \mathrm{sbr}$ & $\sim 245, \sim 245 \mathrm{vsbr}$ & $\sim 255, \sim 255$ & $\sim 230, \sim 235$ \\
\hline & $\nu_{4}$ (TeCl bend. $)$ & $\sim 136, \sim 134 \mathrm{Vw}$ & $\sim \underline{122} \mathrm{vw}$ & $\sim \underline{120} \mathrm{vw}$ & $\sim 140, \sim \underline{150} \mathrm{~m}$ & $\sim 140,136,128$ & 120 \\
\hline & $\nu_{8}(\mathrm{TeCl}$ bend. $)$ & & & & & $115, \underline{109}$ & 100 \\
\hline & $\begin{array}{c}\nu_{23} \text { anion cation } \\
\text { translations }\end{array}$ & $66,66 \mathrm{~m}$ & $64,66 \mathrm{~m}$ & & $\sim 106, \sim \underline{106} \mathrm{~m}$ & $87, \underline{97}, \underline{92}, 87$ & $75, \underline{80}, \underline{60}$ \\
\hline
\end{tabular}

IIntensity codes: vs=very strong, $\mathrm{m}=$ medium, $\mathrm{vw}=$ very weak, br=broad. $\quad$ For $\mathrm{K}$ and $\left(\mathrm{CH}_{3}\right)_{4} \mathrm{~N}$, see Figs. 5 and 6 .

pressed into discs suitable for recording far ir spectra with an RIIC-FS-720/FTC-300 interferometer, equipped with a variable temperature liquid-nitrogen cryostat. The temperature of the mounting frame was measured with a thermoelement. The Raman spectra were obtained on powdered samples in glass capillary ampoules, excited by a CR500 K Kr laser operating at $647.1 \mathrm{~nm}$. The power of the beam was at the 20-80 $\mathrm{mW}$ level, measured after passing a narrow bandpass filter. Light scattered $\sim 90^{\circ}$ was collected with a lens, passed through a scrambler, and sent into a Jeol JRS-400D double monochromator equipped with concave holographic gratings (Jobin-Yvon). The signal was detected with an extended $\mathbf{S}-20$ photomultiplier (HTV) at room temperature and amplified in a photon counting system. The sample temperature was controlled by means of a variable temperature liquid-nitrogen cryostat. The temperature of the copper block which surrounded the ampoule was measured with a Pt resistance thermometer. A more accurate sample temperature was estimated in several cases by ratioing Stokes and anti-Stokes intensities of bands close to the laser line.

The spectral resolution was $\sim 3 \mathrm{~cm}^{-1}$ both in ir and in Raman, The instruments were calibrated with $\mathrm{H}_{2} \mathrm{O}$ vapor and $\mathrm{Kr}^{+}$lines, respectively, and the vacuum wave numbers quoted are considered accurate within $\sim 2 \mathrm{~cm}^{-1}$.

\section{RESULTS AND DISCUSSION}

\section{A. General}

Average tracings of the spectra obtained are reproduced in Figs, 4-6. Frequencies and assignments for the six compounds are given in Table III. Apart from small differences in band positions and shapes, the spectral features of the compounds $\mathrm{Rb}_{2}\left[\mathrm{TeCl}_{6}\right]$, $\mathrm{Cs}_{2}\left[\mathrm{TeCl}_{6}\right],\left(\mathrm{NH}_{4}\right)_{2}\left[\mathrm{TeCl}_{6}\right]$, and $\mathrm{Tl}_{2}\left[\mathrm{TeCl}_{6}\right]$ are almost insensitive to cooling (Fig. 4). The spectra of
$\left(\left(\mathrm{CH}_{3}\right)_{4} \mathrm{~N}\right)_{2}\left[\mathrm{TeCl}_{6}\right]$ and $\mathrm{K}_{2}\left[\mathrm{TeCl}_{6}\right]$ show separate temperature dependent low-frequency features, (Figs. 5 and 6).

The Raman bands near the laser line $\left(0-200 \mathrm{~cm}^{-1}\right)$ have been observed in anti-Stokes scattering as well, which excluded them from being laser plasma lines. The low temperatures achieved in the far ir spectra are believed to be slightly lower than those of the Raman owing to the sample heating in the laser beam. All the observed changes in spectra with temperature were reversible.

\section{B. Cubic compounds}

The room temperature results of the literature $\mathrm{e}^{10-18,20}$ were generally reproduced. The Raman active lattice

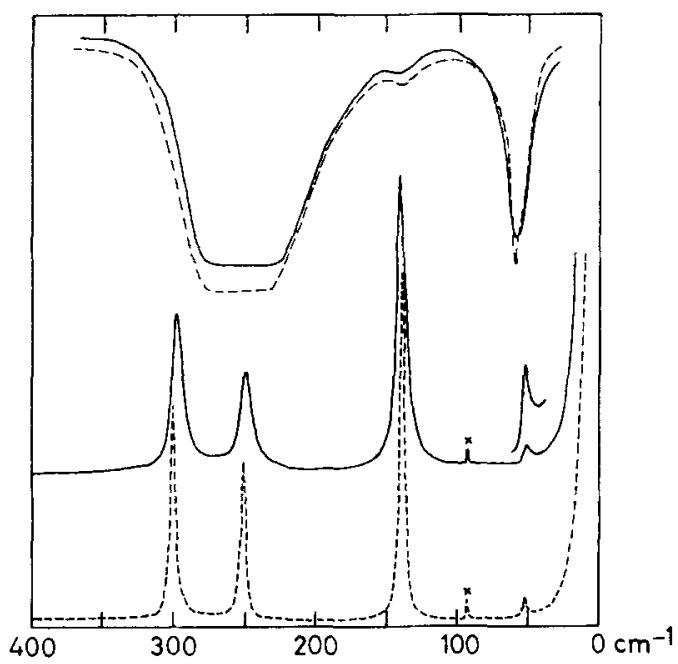

FIG. 4. $\mathrm{Rb}_{2}\left[\mathrm{TeCl}_{6}\right]$. Far infrared transmission spectra of powder in a pressed polyethylene disc (upper lines) and Raman scattering spectra of powder in a glass ampoule (lower lines). Solid lines: ambient temperature $(\sim 300 \mathrm{~K})$; dashed lines: low temperature $(\sim 100 \mathrm{~K})$. A laser plasma line marked with $x$ occurs at $94 \mathrm{~cm}^{-1}$. 


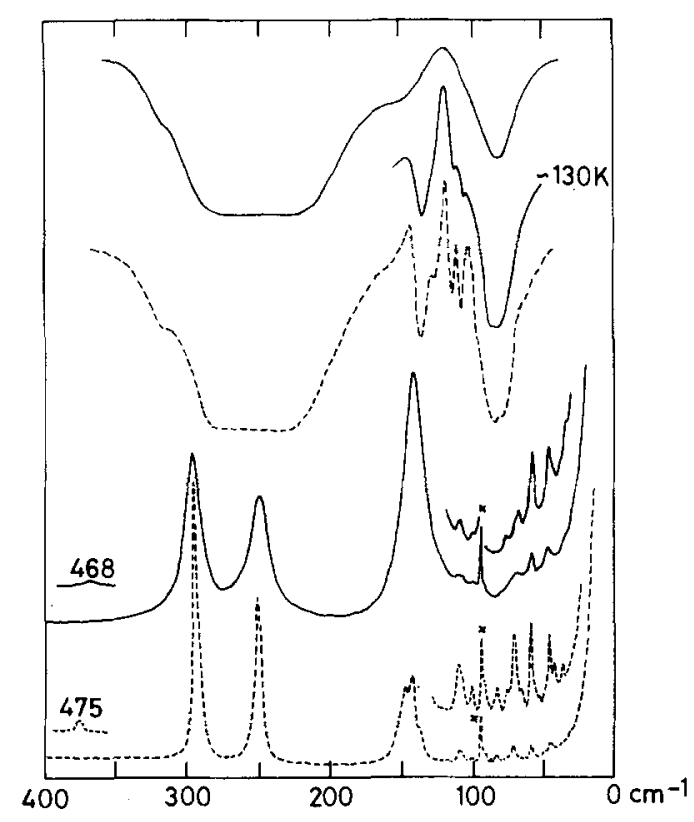

FIG. 5. $\mathrm{K}_{2}\left[\mathrm{TeCl}_{6}\right]$. Far infrared transmission and Raman scattering spectra. Conditions are explained in Fig. 4.

mode $\nu_{L 2}$ which has never been reported before was seen in the $\mathrm{Rb}_{2}\left[\mathrm{TeCl}_{6}\right], \mathrm{Cs}_{2}\left[\mathrm{TeCl}_{6}\right],\left(\mathrm{NH}_{4}\right)_{2}\left[\mathrm{TeCl}_{6}\right]$, and $\left(\left(\mathrm{CH}_{3}\right)_{4} \mathrm{~N}\right)_{2}\left[\mathrm{TeCl}_{6}\right]$ salts. In $\left(\mathrm{NH}_{4}\right)_{2}\left[\mathrm{TeCl}_{6}\right], \nu_{L 2}$ was observed (near $104 \mathrm{~cm}^{-1}$ ) only at low temperature. A band at $53 \mathrm{~cm}^{-1}$ quoted by Hendra and Jovic ${ }^{11}$ could not be verified. Although the $\mathrm{Tl}_{2}\left[\mathrm{TeCl}_{6}\right]$ ir spectra were of poor quality, the Raman results were in accordance with previous ones, ${ }^{15}$ thus confirming the high $\nu_{2}$ and low $\nu_{5}$ frequencies in this compound.

Since the translational lattice vibrations are relative motions of cations and hexachlorotellurate ions $\left(\nu_{L 3}\right)$ and of cations alone $\left(\nu_{L 2}\right)$, their frequencies should depend strongly upon the cation mass. If the simple harmonic oscillator approximation is used, force constants can be calculated as shown in Table IV. The average value of $k_{L 2}(\simeq 0.16 \mathrm{mdyn} / \AA)$ will be used in the discussion on $\mathrm{K}_{2}\left[\mathrm{TeCl}_{6}\right]$. The rather constant value of $k_{L 2}$ and $k_{L 3}$ from crystal to crystal is indication of a small degree of coupling between translational and anion internal modes. This situation has been found previously ${ }^{18}$ and is possible, as has been shown theoretically by Gans, ${ }^{30}$ even though the frequency separations between $\nu_{5}$ and $\nu_{L 2}$, and $\nu_{4}$ and $\nu_{L 3}$, respectively, are quite small.

\section{C. $\mathrm{K}_{2}\left[\mathrm{TeCl}_{6}\right]$}

Literature results ${ }^{9,10,18,20}$ were generally confirmed. It is evident already at room temperature that the monoclinic structure gives rise to numerous new bands; only the $88 \mathrm{~cm}^{-1}$ ir band and questionable ir bands at 108 and $98 \mathrm{~cm}^{-110}$ and $70 \mathrm{~cm}^{-118}$ have previously been reported below $135 \mathrm{~cm}^{-1}$. It is possible to assign the new room temperature bands (Fig. 5) by reference to the predictions (Table II). In a reasonable approximation, the $\nu_{6}\left[\mathrm{TeCl}_{6}\right]^{2-}$ bending mode (of symmetry species $T_{2 u}$ in a perfect octahedral configuration) should occur at a frequency $\nu_{6} \simeq \nu_{5} / \sqrt{2}{ }^{31}$ Our $\nu_{5}$ value thus
TABLE IV. Harmonic oscillator force constants $k=4 \pi^{2} \mu \nu^{2}$ for the external lattice vibrations $\nu_{L 2}$ and $\nu_{L 3}$ in cubic $\mathrm{A}_{2}\left[\mathrm{TeCl}_{6}\right]$ salts. Reduced masses $\mu_{L 2} \simeq M_{\mathrm{A}}$ and $\mu_{L 3} \simeq M_{2 \mathrm{~A}} M_{\mathrm{TeCl}_{6}}$ ' $\left(M_{2 \mathrm{~A}}+M_{\mathrm{TeCl}_{6}}\right)$ were used $\left(M_{\mathrm{A}}=\right.$ mass of $\left.\mathrm{A}\right)$.

\begin{tabular}{lll}
\hline \hline $\mathrm{A}$ & $\begin{array}{l}\text { Raman active } \nu_{L 2} \\
(\mathrm{mdyn} / \AA)\end{array}$ & $\begin{array}{l}\text { ir active } \nu_{L 3} \\
(\mathrm{mdyn} / \AA)\end{array}$ \\
\hline $\mathrm{Rb}$ & 0.14 & 0.29 \\
$\mathrm{Cs}$ & 0.20 & 0.36 \\
$\mathrm{NH}_{4}$ & 0.12 & 0.22 \\
$\left(\mathrm{CH}_{3}\right)_{4} \mathrm{~N}$ & 0.18 & 0.34 \\
\hline \hline
\end{tabular}

gives $\nu_{6} \simeq 100 \mathrm{~cm}^{-1}$ in agreement with the value 103 $\mathrm{cm}^{-1}$ found by Adams and Morris ${ }^{10}$ using a modified Urey-Bradley force field and an estimated value of $\nu_{4} \simeq 139 \mathrm{~cm}^{-1}$. In the $C_{2 h}^{3}$ symmetry $\nu_{6}$ is ir allowed and it therefore seems reasonable to assign $\nu_{B}$ to the two sharp low-temperature bands just near $100 \mathrm{~cm}^{-1}$ and to let $\nu_{4}$ be the two bands around $140 \mathrm{~cm}^{-1}$, in accordance with the commonly accepted value for $\nu_{4}$. To interpret the room temperature Raman spectrum we assumed that the approximate force constant $k_{L 2} \simeq 0.16 \mathrm{mdyn} /$ $\AA$ (just found for the cubic $\mathrm{A}_{2}\left[\mathrm{TeCl}_{8}\right]$ salts) also has some relevance in $\mathrm{K}_{2}\left[\mathrm{TeCl}_{6}\right]$. The harmonic oscillator model then gives $\nu_{L 2} \simeq 83 \mathrm{~cm}^{-1}$. The monoclinic field splits the cubic $\nu_{L 2}$ mode into $2 A_{g}+B_{g}$ (Table II), and thus it seems tempting to assign the bands at 109 and $70 \mathrm{~cm}^{-1}$ to cation translations $\nu_{L 2}$. Furthermore, in a work on the vibrational spectra of 31 cubic hexachloro and bromo metallates $\mathrm{A}_{2}\left[\mathrm{MX}_{6}\right]$, Debeau and Poulet, ${ }^{32}$ using a modified Urey-Bradley crystal force field and the method due to Shimanouchi, Tsuboi, and Miyazawa, ${ }^{33}$ calculated the internal and external $\mathbf{k} \simeq 0$ phonon frequencies. For all the eight potassium compounds (tellurates not included), they found the external

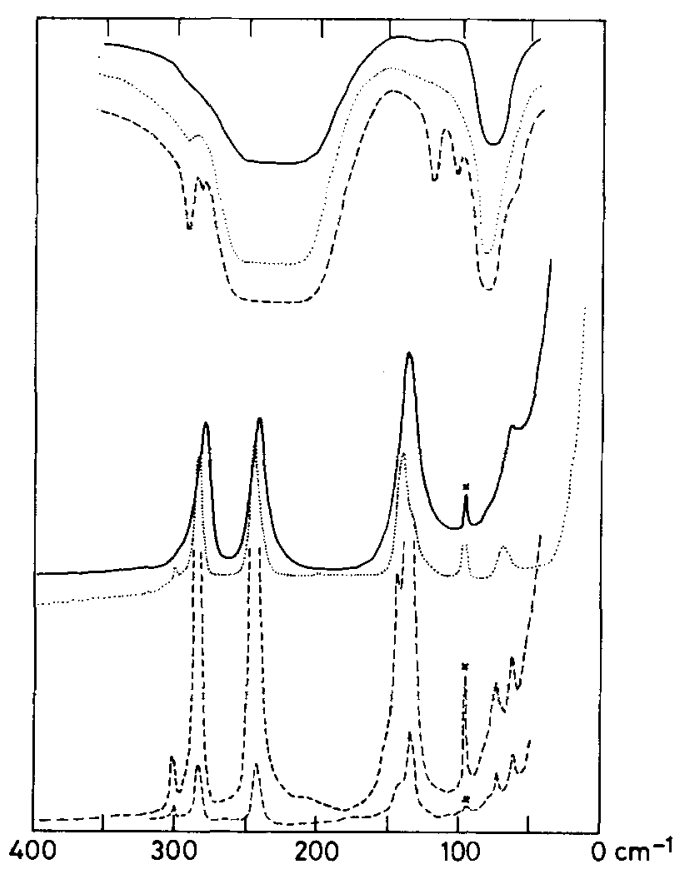

FIG. 6. $\left(\left(\mathrm{CH}_{3}\right)_{4} \mathrm{~N}\right)_{2}\left[\mathrm{TeCl}_{6}\right]$. Far infrared transmission and Raman scattering spectra. Conditions are explained in Fig. 4. Dotted lines: low temperature $(\sim 140 \mathrm{~K})$. 
frequencies to decrease in the order $\nu_{L 3}>\nu_{L 2}>\nu_{L 1}$. Because of this we suggest that the triplet of $\left[\mathrm{TeCl}_{6}\right]^{2-}$ rotational modes $\nu_{L 1}$ (Table II) be assigned to the roomtemperature Raman bands at 59,48 , and $36 \mathrm{~cm}^{-1}$.

The low-temperature Raman spectrum of $\mathrm{K}_{2}\left[\mathrm{TeCl}_{6}\right]$ presents an interesting problem. According to Table II, a maximum of six different bands should occur owing to first order Raman scattering by each one of the six external lattice modes. Experimentally, 11 peaks are observed below $110 \mathrm{~cm}^{-1}$ (Fig. 5). Seeking an explanation for this, we considered the possibilities for second order processes. In the centrosymmetric $C_{2 h}^{3}$ cell, $g \times g$ and $u \times u$ modes are probable candidates for second order Raman activity (at the Brillouin zone center $\Gamma$ ), and we note that bands at $\sim 101, \sim 93$, and $\sim 84 \mathrm{~cm}^{-1}$ might arise from the combinations $38+60,43+60$; $43+47,47+47 ;$ and $38+43,38+47,43+43$, respective1y. On the other hand, it is quite difficult to explain the presence of the "wings" of the $72 \mathrm{~cm}^{-1}$ band and the four bands in the $\nu_{L 1}$ range below $60 \mathrm{~cm}^{-1}$; longitudinaltransversal mode splitting being precluded in the centrosymmetric cell.

As a simpler explanation, we suggest the presence of a phase transition with unit cell multiplication. Should this be the case, the Brillouin zone is reduced by folding such that certain zone boundary phonons become zone center modes and therefore eventually may become Raman active by first order. It is instructive to compare this hypothesis of a phase transition with the analogous situation in $\mathrm{K}_{2}\left[\mathrm{PtCl}_{6}\right], \mathrm{K}_{2}\left[\mathrm{ReCl}_{6}\right]$, and

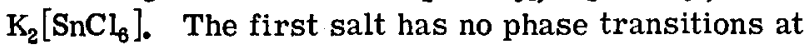
all. ${ }^{28}$ In $\mathrm{K}_{2}\left[\mathrm{ReCl}_{6}\right]$, the room temperature crystal of $O_{h}^{5}$ symmetry is transformed three times during cooling, ${ }^{28}$ probably via the space groups $C_{4 h}^{5}$ and $C_{4 h}^{4}$ ending up at $\sim 20 \mathrm{~K}$ with the fourfold increased noncentrosymmetric $T_{h}^{2}$ cell. $\mathrm{K}_{2}\left[\mathrm{SnCl}_{8}\right]$ showed somewhat similar behavior. ${ }^{29}$ In the low temperature $(\sim 10 \mathrm{~K})$ Raman spectra of the Re and Sn compounds, a quite strong and sharp (and soft) $\nu_{L 1}$ rotatory and a weaker $\nu_{L 2}$ translatory mode were assigned $^{2 \theta_{2} 29}$ near 30 and $80 \mathrm{~cm}^{-1}$, respectively. Furthermore, bands near 60 and $90 \mathrm{~cm}^{-1}$ were assigned as due to $\mathrm{k} \simeq 0$ phonons (in the low temperature structure), phonons which originate from $X$-point phonons of the cubic Brillouin zone.

Comparing these results with our spectrum of $\mathrm{K}_{2}\left[\mathrm{TeCl}_{6}\right]$, which has similar bands at $\sim 100 \mathrm{~K}$ (Fig. 6), we do not consider a cell multiplication in $\mathrm{K}_{2}\left[\mathrm{TeCl}_{6}\right]$ at lower temperatures as being improbable. Rather, such a phase transition would explain the quite sudden appearance of the $\nu_{6}$ ir bands near $\sim 165 \mathrm{~K}$. These bands were just detectable at $\sim 175 \mathrm{~K}$ and distinct at $\sim 155 \mathrm{~K}$ (a spectrum obtained at $\sim 130 \mathrm{~K}$ is given in Fig. 5). In this light, it is not clear whether the splitting of $\nu_{5}$ depends on the phase transition or not. We have not yet investigated the Raman bands for any possible softening near $\sim 165 \mathrm{~K}$.

\section{D. $\left(\left(\mathrm{CH}_{3}\right)_{4} \mathrm{~N}\right)_{2}\left[\mathrm{TeCl}_{6}\right]$, phase transition}

It is clear from Fig. 6 that a phase transition takes place in $\left(\left(\mathrm{CH}_{3}\right)_{4} \mathrm{~N}\right)_{2}\left[\mathrm{TeCl}_{6}\right]$ between 140 and $100 \mathrm{~K}$. We had difficulties in introducing the transformation in some samples, but it has been observed several times on different samples. Apparently the high temperature phase can sometimes be supercooled to $\sim 80 \mathrm{~K}$ (unexposed to laser light) for hours without change. We explain it as hysteresis of transition, although it may be due to the combined effect of irradiance heating during the measurement and low cooling efficiency of our powder setup.

Averaging the ir and Raman results, the conversion temperature $\left(T_{c}\right)$ is estimated to be about $110 \pm 15 \mathrm{~K}$. Essentially, the room temperature spectra were always observed at $\sim 140 \mathrm{~K}$ (Fig. 6), except for small signs of what will happen during the transformation (maybe due to small unstable domains of the low temperature phase).

By means of electronic ${ }^{34}$ and Raman ${ }^{23}$ spectroscopy, similar phase transitions of quoted first order have been found near $\sim 123 \mathrm{~K}$ in $\left(\left(\mathrm{CH}_{3}\right)_{4} \mathrm{~N}\right)_{2}\left[\mathrm{UCl}_{8}\right]$, near $\sim 149$ $\mathrm{K}$ in $\left(\left(\mathrm{CH}_{3}\right)_{4} \mathrm{~N}\right)_{2}\left[\mathrm{SnCl}_{6}\right]$, and in $\left(\left(\mathrm{CH}_{3}\right)_{4} \mathrm{~N}\right)_{2}\left[\mathrm{ZrCl}_{6}\right]\left(T_{C}\right.$ not known). Both the $\mathrm{U}$ and $\mathrm{Sn}$ compounds exhibited hysteresis, though not so much as found here: $T_{c}$ differed up to $15 \mathrm{~K}$ depending on whether the determination was made with decreasing or increasing temperature. It was also found ${ }^{23,34}$ that the high temperature phases deviated slightly from being totally cubic $O_{h}^{5}$ :

(i). The electronic Laporte selection rule was violated in $\left(\left(\mathrm{CH}_{3}\right)_{4} \mathrm{~N}\right)_{2}\left[\mathrm{UCl}_{6}\right],{ }^{34}$ hence this compound is slightly noncentrosymmetric at $T>T_{C}$.

(ii). The Raman spectra of the high temperature phase of both the $U$ and $\mathrm{Sn}$ compound contained fundamentals which in high resolution at lower temperatures were split into close doublets, again indicating ${ }^{23}$ slight deviations from the $\mathrm{K}_{2}\left[\mathrm{PtCl}_{6}\right]$ structure.

(iii). Adams and Morris ${ }^{10}$ reported the appearance of weak forbidden lines (in $O_{h}^{5}$ ) in x-ray powder photographs of $\left(\left(\mathrm{CH}_{3}\right)_{4} \mathrm{~N}\right)_{2}\left[\mathrm{PtCl}_{6}\right]$ at ambient temperature. Previously, many $\left(\left(\mathrm{CH}_{3}\right)_{4} \mathrm{~N}\right)_{2}\left[\mathrm{MX}_{6}\right]$ crystals have been shown mainly by $\mathrm{x}$-ray methods to belong to the $O_{h}^{5}$ $\mathrm{K}_{2}\left[\mathrm{PtCl}_{6}\right]$ lattice; both compounds $\left\{\right.$ e.g., $\left(\left(\mathrm{CH}_{3}\right)_{4} \mathrm{~N}\right)_{2}$ $\times\left[\mathrm{MnCl}_{6}\right],{ }^{35}\left(\left(\mathrm{CH}_{3}\right)_{4} \mathrm{~N}\right)_{2}\left[\mathrm{PtCl}_{6}\right],{ }^{36}$ and $\left.\left(\left(\mathrm{CH}_{3}\right)_{4} \mathrm{~N}\right)_{2}\left[\mathrm{SnCl}_{6}\right]^{37}\right\}$ having $\mathrm{MX}$ (metal-halogen) distances much smaller than the $2.52 \AA$ typical for $\mathrm{TeCl}$ bonds ${ }^{2,5}$ and compounds with longer $\mathrm{MX}$ distances $\left\{\mathrm{e} . \mathrm{g}\right.$. , $\left(\left(\mathrm{CH}_{3}\right)_{4} \mathrm{~N}\right)_{2}\left[\mathrm{CeCl}_{6}\right]^{38}$ and $\left.\left(\left(\mathrm{CH}_{3}\right)_{4} \mathrm{~N}\right)_{2}\left[\mathrm{UCl}_{6}\right]^{39}\right\}$.

Preliminary Raman spectra in the range $3500-50 \mathrm{~cm}^{-1}$ at room temperature and at a resolution of $\sim 3 \mathrm{~cm}^{-1}$ were measured on $\left(\left(\mathrm{CH}_{3}\right)_{4} \mathrm{~N}\right)_{2}\left[\mathrm{TeCl}_{6}\right]$ and $\left(\left(\mathrm{CH}_{3}\right)_{4} \mathrm{~N}\right)_{2}\left[\mathrm{PtCl}_{6}\right]$, which also has a low temperature transition. ${ }^{40}$ The spectra showed no indication of splittings of the fundamental bands, with the possible exception of the band at $\sim 455 \mathrm{~cm}^{-1}$. The spectra were very similar to that of $\left(\left(\mathrm{CH}_{3}\right)_{4} \mathrm{~N}\right)_{2}\left[\mathrm{SnCl}_{8}\right]$, obtained on powder at room temperature, ${ }^{22}$ under which conditions its known splittings were also unresolved. Hence, by analogy, we conclude that $\left(\left(\mathrm{CH}_{3}\right)_{4} \mathrm{~N}\right)_{2}\left[\mathrm{TeCl}_{6}\right]$ may deviate slightly from being cubic at room temperature like the $\mathrm{U}, \mathrm{Sn}$, and Pt compounds, but until proved we describe it as such, in accordance with the single index of refraction $(1.605)$ reported ${ }^{39}$ for $\left(\left(\mathrm{CH}_{3}\right)_{4} \mathrm{~N}\right)_{2}\left[\mathrm{TeCl}_{6}\right]$ crystals. 
The spectra of the low temperature phase of $\left(\left(\mathrm{CH}_{3}\right)_{4} \mathrm{~N}\right)_{2}\left[\mathrm{TeCl}_{6}\right](\mathrm{Fig} .6)$ are clearly not understandable in terms of the selection rules of Table $\mathrm{I}$, and hence (like for the $U$ and $S n$ compounds) ${ }^{23}$ it must have another structure, either with a lower symmetry or a larger cell. Using the data available, Ohe ${ }^{23}$ suggested that the space group of $\left(\left(\mathrm{CH}_{3}\right)_{4} \mathrm{~N}\right)_{2}\left[\mathrm{UCL}_{6}\right]$ at room temperature was $D_{2 d}^{11}$ and that the compound during the transformation is changed to have either $C_{4 h}^{5}$ symmetry or a two formula unit primitive volume. Apparently, $\mathrm{Ohe}^{23}$ did not consider the possibility in piezoelectric space groups for longitudinal-transversal splitting of modes which at the same time are ir and Raman active. ${ }^{41}$ In $D_{3}$ the $E$-type modes are both ir and Raman active, so that Ohe's observation of splittings of bands known to be of $E_{g}$ type (in $O_{h}^{5}$ ) is no proof of $D_{2 d}^{11}$ being the only space group of the high temperature phase of $\left(\left(\mathrm{CH}_{3}\right)_{4} \mathrm{~N}\right)_{2}$ $\times\left[\mathrm{UCl}_{6}\right]$; it could equally well, for example, be $D_{3}^{7}$. Evidently the $L O-T O$ splitting possibility complicates the structural derivations to a level where such deductions are not very reliable.

Instead, we therefore assumed a common reason for all the phase transitions and considered what may be unified and possible causes for the transformations. Of course, it is not known if such an assumption is justified; different things might occur in different crystals.

(i). Cation reorientation. The chemical literature on tetramethylammonium compounds comprises examples of crystal structures with orientationally ordered ${ }^{42-47}$ as well as disordered/rotating $\left(\mathrm{CH}_{3}\right)_{4} \mathrm{~N}^{+}$ ions. ${ }^{48,49}$ Most interestingly, the $\mathrm{X}$-ray structure determinations ${ }^{37,38,42}$ of $\left(\left(\mathrm{CH}_{3}\right)_{4} \mathrm{~N}\right)_{2}\left[\mathrm{SnCl}_{6}\right],\left(\left(\mathrm{CH}_{3}\right)_{4} \mathrm{~N}\right)_{2}$ $\times\left[\mathrm{CeCl}_{6}\right]$, and $\left(\left(\mathrm{CH}_{3}\right)_{4} \mathrm{~N}\right)_{2}\left[\mathrm{~B}_{6} \mathrm{H}_{6}\right]$ (which also crystallize in the $\mathrm{K}_{2}\left[\mathrm{PtCl}_{6}\right]$ structure with octahedral $\left[\mathrm{B}_{6} \mathrm{H}_{6}\right]^{2-} \mathrm{re}-$ placing the $\left[\mathrm{PtCl}_{6}\right]^{2-}$ ions) ${ }^{42}$ revealed the positions of the $\mathrm{C}$ atoms. These results indicated orientational ordering of the $\left(\mathrm{CH}_{3}\right)_{4} \mathrm{~N}^{+}$ions in the configuration named perpendicular by Ohe, ${ }^{22}$ and characterized by $\mathrm{C}-\mathrm{N}$ bonds not pointing towards the $M$ atoms. Presumably, this is likewise the case in other $\left(\left(\mathrm{CH}_{3}\right)_{4} \mathrm{~N}\right)_{2}\left[\mathrm{MX} \mathrm{M}_{6}\right]$ crystals. It has indeed been found also in the tetragonal distorted $\left(\left(\mathrm{CH}_{3}\right)_{4} \mathrm{~N}\right)_{2}\left[\mathrm{SiF}_{6}\right]_{0}{ }^{50}$ Then, since the $\left(\mathrm{CH}_{3}\right)_{4} \mathrm{~N}^{+}$ions are already orientationally ordered at room temperature, the transformation is not likely to be driven by the reorientational freedom of the $\left(\mathrm{CH}_{3}\right)_{4} \mathrm{~N}^{*}$ ions, although the equilibrium position may be changed.

(ii). Methyl group rotation. The methyl groups of $\left(\mathrm{CH}_{3}\right)_{4} \mathrm{~N}^{*}$ ions have been claimed to rotate quite freely around the $\mathrm{C}-\mathrm{N}$ bonds in various salts, ${ }^{46} \mathrm{4}_{4} 4 \mathrm{~B}_{0} 51$ while in others they are believed $26,42,45,52,53$ to be confined to torsional oscillation (librations), sometimes around twofold disordered equilibrium positions. ${ }^{47}$ Interestingly, $\left(\left(\mathrm{CH}_{3}\right)_{4} \mathrm{~N}\right)_{2} \mathrm{SO}_{4} \cdot 4 \mathrm{H}_{2} \mathrm{O}$ seems to contain both rotating/ disordered and nonrotating/ordered methyl groups. ${ }^{44}$ A calorimetrically detected phase transition near 406 $\mathrm{K}$ in $\left(\left(\mathrm{CH}_{3}\right)_{4} \mathrm{~N}\right)_{2}\left[\mathrm{~B}_{6} \mathrm{H}_{6}\right]$ has been assigned to the onset of methyl rotation ${ }^{42}$; below that temperature the methyl groups were found fixed in the staggered conformation, as defined in Refs. 23 and 52 . The hydrogen atoms in $\left(\mathrm{CH}_{3}\right)_{4} \mathrm{~N}\left[\mathrm{FeCl}_{4}\right]$ at room temperature seem to be con- fined to the staggered conformation as well. ${ }^{45}$ Taken together, all this $\mathrm{x}$-ray diffraction evidence shows that $\left(\left(\mathrm{CH}_{3}\right)_{4} \mathrm{~N}\right)_{2}\left[\mathrm{MCl}_{6}\right]$ compounds might have rotating methyl groups at room and lower temperatures and that the phase transitions observed might involve the "freezing out" of one or more of these degrees of freedom. The structural change cannot be due to methyl fixation alone, since this probably would leave us with the staggered, perpendicular structure, which being still cubic $O_{n}^{5}$ cannot explain the spectra. Something else must happen.

(iii). Weak hydrogen bonding . It was recently demonstrated by ir spectroscopy ${ }^{26}$ that the $\left(\mathrm{CH}_{3}\right)_{4} \mathrm{~N}^{*}$ ion probably is able to form $\mathrm{C}-\mathrm{H} \cdots \mathrm{X}$ hydrogen bonds to neighboring halide anions but not to, for example, $\left[\mathrm{SnCl}_{6}\right]^{2-}$ and $\left[\mathrm{SiF}_{6}\right]^{2-}$, at room temperature. On this basis it might be anticipated that $\mathrm{C}-\mathrm{H} \cdot \mathrm{Cl}$ interactions, though weak, could become structurally important in $\left(\left(\mathrm{CH}_{3}\right)_{4} \mathrm{~N}\right)_{2}\left[\mathrm{MCl}_{6}\right]$ crystals at lower temperatures by slightly changing the packing forces and thus introducing small anisotropic distortions. Assuming $\left(\left(\mathrm{CH}_{3}\right)_{4} \mathrm{~N}\right)_{2}\left[\mathrm{TeCl}_{6}\right]$ to be of perpendicular and staggered configuration and having the reasonable estimated lattice parameters $a \simeq 13,0 \AA, R(\mathrm{Te}-\mathrm{Cl}) \simeq 2.52 \AA,{ }^{2-5}$ $R(\mathrm{C}-\mathrm{N}) \simeq 1.40 \AA, R(\mathrm{C}-\mathrm{H}) \simeq 1.09 \AA$ and all $\left(\mathrm{CH}_{3}\right)_{4} \mathrm{~N}^{+}$ angles $\simeq 109.47^{\circ}, 37,38,42-50$ we calculate the $\mathrm{C}-\mathrm{H} \cdots \mathrm{Cl}$ distance to $3.8 \AA$, in close agreement with the value for quoted hydrogen bonded $\left(\mathrm{CH}_{3}\right)_{4} \mathrm{NCl}{ }^{26}$ We take this as an indication of the possibility of weak hydrogen bonding in $\left(\left(\mathrm{CH}_{3}\right)_{4} \mathrm{~N}\right)_{2}\left[\mathrm{MX}_{8}\right]$ crystals at lower temperature. This might cause "freezing out" of the methyl torsions, cation displacements (e.g., along the [111] direction producing a trigonal crystal) or cation reorientation (e.g., around the $z$ axis, reducing the symmetry to a tetragonal space group), all in order to make more efficient packing. Eventually this process may distort the $T_{d}$ symmetry of the $\left(\mathrm{CH}_{3}\right)_{4} \mathrm{~N}^{+}$cations.

(iv). Distortions of anion lattice. As discussed for $\mathrm{K}_{2}\left[\mathrm{TeCl}_{6}\right]$, anion rotations or translations may change the space left for the cations. In the phase transitions of $\left(\left(\mathrm{CH}_{3}\right)_{4} \mathrm{~N}\right)_{2}\left[\mathrm{MCl}_{6}\right]$ crystals considered here, such distortions of the $\left[\mathrm{MCl}_{6}\right]^{2-}$ sublattice might operate as well, eventually in combination with one or more of the principles discussed above. Finally, a deformation of the $\left[\mathrm{MCl}_{6}\right]^{2-}$ octahedron should be considered. A possible distortion would be an elongation or compression along the directions [111] or [001], eventually in cooperation with (iii). Because of the quite close correspondence in behavior of the $\mathrm{U}, \mathrm{Sn}, \mathrm{Zr}, \mathrm{Pt}$, and $\mathrm{Te}$ compounds, we are convinced that an eventual deformation of the $\left[\mathrm{TeCl}_{6}\right]^{2-}$ octahedron is unaffected by the presence of the lone pair of electrons and thus would have no relation to the Gillespie effect. ${ }^{1}$

(v). Analogy to the hexafluorosilicate. It is interesting to note that the space group $C_{4 h}^{5}$ deduced by $\mathrm{Ohe}^{23}$ as a possibility for the low temperature phase of $\left(\left(\mathrm{CH}_{3}\right)_{4} \mathrm{~N}\right)_{2}\left[\mathrm{UCl}_{6}\right]$ is the same space group as that found by $\mathrm{x}$-ray methods for $\left(\left(\mathrm{CH}_{3}\right)_{4} \mathrm{~N}\right)_{2}\left[\mathrm{SiF}_{6}\right] .{ }^{50}$ In this tetragonally distorted antifluorite structure the $\left[\mathrm{SiF}_{\mathrm{B}}\right]^{2-}$ octahedra were all found to be rotated $\sim 34^{\circ}$ clockwise and the $\left(\mathrm{CH}_{3}\right)_{4} \mathrm{~N}^{+}$tetrahedra all $\sim 12^{\circ}$ counterclockwise, 
in both cases around the $z$ axis. The methyl groups contacted at $\sim 3.41 \AA$ with three fluorine atoms, each from separate $\left[\mathrm{SiF}_{6}\right]^{2-}$ octahedra. Each fluorine was equidistantly surrounded by four methyl groups, and the $\left(\mathrm{CH}_{3}\right)_{4} \mathrm{~N}^{+}$tetrahedra were in contact with each other. The low temperature structures of the $\left(\left(\mathrm{CH}_{3}\right)_{4} \mathrm{~N}\right)_{2}\left[\mathrm{MCl}_{6}\right]$ salts could very well be quite similar to this structure. One might object to this, that the $\left[\mathrm{SiF}_{6}\right]^{2-}$ octahedron is much smaller $[R(\mathrm{Si}-\mathrm{F}) \simeq 1.7 \AA]^{50}$ than, for example, the $\left[\mathrm{SnCl}_{6}\right]^{2-}$ octahedron $[R(\mathrm{Sn}-\mathrm{Cl}) \simeq 2.4 \AA]{ }^{22}$ On the other hand, it is known that, for example, $\left(\mathrm{NH}_{4}\right)_{2}\left[\mathrm{SiF}_{6}\right]$ and $\left(\left(\mathrm{CH}_{3}\right)_{4} \mathrm{~N}\right)_{2}\left[\mathrm{IrF}_{6}\right]$ are cubic at room temperature. ${ }^{54,55}$ As pointed out by Ohe, ${ }^{23}$ the selection rules of a $C_{4 h}^{5}$ structure are well suited to an account of the number of observed low temperature bands.

\section{E. $\left(\left(\mathrm{CH}_{3}\right)_{4} \mathrm{~N}\right)_{2}\left[\mathrm{TeCl}_{6}\right]$. Spectra}

As we already noted, the room temperature results of the literature ${ }^{8,10,12,20}$ were generally confirmed in our work. In this salt minor ir bands (at $\sim 105 \mathrm{~cm}^{-1}$ assigned to $\nu_{4}^{8,10}$ and at $\sim 247 \mathrm{~cm}^{-1}$ assigned to $\nu_{4}+\nu_{5}{ }^{12}$ ) could not be verified. Instead we observed the $\nu_{L 2}$ band in Raman.

We shall not attempt to assign all the new bands in the low temperature phase of $\left(\left(\mathrm{CH}_{3}\right)_{4} \mathrm{~N}\right)_{2}\left[\mathrm{TeCl}_{6}\right]$ (cf. Table III), because the structure is strictly unknown and no information on the symmetry species of the bands is available. The new bands near $\sim 300 \mathrm{~cm}^{-1}\left(\sim 301 \mathrm{~cm}^{-1}\right.$ in Raman and $293,284 \mathrm{~cm}^{-1}$ in ir) may be due to $\mathrm{TeCl}$ stretchings, $\mathrm{CH}_{3}$ rotations, or "second order" effects becoming allowed in the less symmetric or larger cell. The assignment of $\nu_{4}$ and $\nu_{6}$ bands were done using arguments similar to those of the $\mathrm{K}_{2}\left[\mathrm{TeCl}_{6}\right]$ case. Some of the bands of lowest frequency may contain intensity contributions from anion or cation librations or splitting of translatory modes as well as the tentatively assigned origin given in Table III.

\section{CONCLUSIONS}

No distortion of the type predicted for $\left[\mathrm{TeCl}_{6}\right]^{2-}$ by Gillespie and Nyholm have been found at $\sim 100 \mathrm{~K}$ in the six compounds investigated. The Raman active external lattice modes of $T_{2 s}$ symmetry in the antifluorite structures have been observed. Spectroscopic evidence for the presence of phase transitions at about $165 \mathrm{~K}$ in $\mathrm{K}_{2}\left[\mathrm{TeCl}_{6}\right]$ and at about $110 \mathrm{~K}$ in $\left(\left(\mathrm{CH}_{3}\right)_{4} \mathrm{~N}\right)_{2}\left[\mathrm{TeCl}_{6}\right]$ has been presented. In the low temperature phases the bendings $\nu_{4}$ and $\nu_{6}$ of the $\left[\mathrm{TeCl}_{6}\right]^{2-}$ octahedron were observed at the frequencies expected. In relation to the other compounds of analogous structures we have suggested what we consider as reasonable explanations for the occurrence of the transitions. However, at the present time not enough is known about what actually occurs during the two phase transitions found here. Further work is needed to clarify the detailed nature of these transformations.

\section{ACKNOWLEDGMENT}

Thanks are due to the Carlsberg Foundation for financial support covering auxiliary equipment.
* To whom correspondence should be sent.

${ }^{1}$ R. J. Gillespie and R. S. Nyholm, Quart. Rev. 11, 339

(1957); R. J. Gillespie, J. Chem. Educ. 47, 18 (1970).

${ }^{2}$ G. Engel, Z. Krist, 90, 341 (1935).

${ }^{3}$ A. C. Hazell, Acta Chem. Scand. 20, 165 (1966); E. E. Aynsley and A. C. Hazell, Chem. Ind. (London) 1963, 611 (1963).

${ }^{4}$ I. D. Brown, Can. J. Chem. 42, 2758 (1964).

${ }^{5} \mathrm{M}$. Webster and P. H. Collins, J. Chem. Soc. Dalton Trans. $1973,588$.

${ }^{6}$ D. Nakamura, K. Ito, and M. Kubo, J. Am. Chem. Soc. 84, 163 (1962); M. Kubo and D. Nakamura, Adv. Inorg. Chem. Radiochem. 8, 257 (1966).

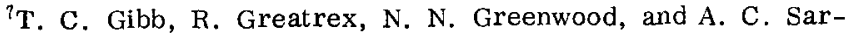
ma, J. Chem. Soc. A 1970, 212.

${ }^{8}$ N. N. Greenwood and B. P. Straughan, J. Chern. Soc. A 1966, 962 .

${ }^{9}$ I. R. Beattie and H. Chudzynska, J. Chem. Soc. A 1967, 984.

${ }^{10}$ D. M. Adams and D. M. Morris, J. Chem. Soc. A 1967, 2067.

${ }^{11} \mathrm{P}$. J. Hendra and Z. Jović, J. Chem. Soc. A 1968, 600.

${ }^{12}$ J. A. Creighton and J. H. S. Green, J. Chem. Soc. A 1968 , 808.

${ }^{13}$ I. R. Beattie and T. R. Gilson, Proc. R. Soc. London Ser. A 307, 407 (1968).

${ }^{14}$ D. J. Stufkens, Rec. Trav, Chim, 89, 1185 (1970); D. J. Stufkens and A. Schenk, Rec. Trav. Chim. 90, 190 (1971).

${ }^{15} \mathrm{~F}$. J. Brinkmann and H. Gerding, Rev. Chim. Minerale 8 , 501 (1971).

${ }^{16}$ D. M. Adams and M. H. Lloyd, J. Chem. Soc. A 1971, 878.

${ }^{17}$ D. M. Adams and S. J. Payne, J. Chem. Soc. Dalton Trans. $1974,407$.

${ }^{18}$ J. D. Donaldson, S. D. Ross, J. Silver, and P. J. Watkiss, J. Chem. Soc. Dalton Trans. 1975, 1980.

${ }^{19}$ I. A. Oxton, O. Knop, and M. Falk, Can. J. Chem. 53, 2675 (1975).

${ }^{20}$ D. M. Adams, J. D. Findlay, M. C. Coles, and S. J. Payne, J. Chem. Soc. Dalton Trans. 1976, 371 (1976).

${ }^{21} \mathrm{~F}$. W. Poulsen, N. J. Bjerrum, and O. F. Nielsen, Inorg. Chem. 13, 2693 (1974).

${ }^{22} \mathrm{~W}$. von der Ohe, J. Chem. Phys. 62, 3933 (1975).

${ }^{23} \mathrm{~W}$. von der Ohe, J. Chem. Phys. 63, 2949 (1975).

${ }^{24} \mathrm{~K}$. D. Möller and W. G. Rotschild, Far Infrared Spectroscopy (Wiley-Interscience, London, 1971), p. 289; M. Schlaak, M. Couzi, and P. V. Huong, Ber. Bunsenges. Phys. Chem. 80; 881 (1976).

${ }^{25}$ M. A. Hooper and D. W. James, Aust. J. Chem. 24, 1331 (1971).

${ }^{26}$ K. M. Harmon, I. Gennick, and S. L. Madeira, J. Phys. Chem. 78, 2585 (1974).

${ }^{27}$ A. K. Das and I. D. Brown, Can. J. Chem. 44, 939 (1966).

${ }^{28}$ P. G, O'Leary and R. G. Wheeler, Phys. Rev. B 1, 4909 (1970).

${ }^{29} \mathrm{~J}$. Winter, K. Rössler, J. Bolz, and J. Pelzl, Phys. Status Solidi B 74, 193 (1976); J. Pelzl, W. Henkel, J. Winter, and K. Rössler, Proc. Int. Conf. Raman Spectrosc., 5th, Freiburg, (1976), p. 620; J. Pelzl (personal communication).

${ }^{30} \mathrm{P}$. Gans, Vibrating Molecules (Chapman and Hall, London, 1971), p. 160 .

${ }^{31} \mathrm{H}$. Siebert, Anwendungen der Schwingungsspektroskopie in der Anorganischen Chemie (Springer, Berlin, 1966), p. 83.

${ }^{32} \mathrm{M}$. Debeau and H. Poulet, Spectrochim. Acta A 25, 1553 (1969).

${ }^{33}$ T. Shimanouchi, M. Tsuboi, and T. Miyazawa, J. Chem. Phys. 35, 1597 (1961).

${ }^{34}$ R. A. Satten and E. Y. Wong, J. Chem. Phys. 43, 3025 (1965).

${ }^{35}$ P. C. Moews Jr., Inorg. Chem. 5, 5 (1966).

${ }^{36}$ M. L. Huggins, Phys. Rev. 27, 638 (1926); C. K. Jórgensen, Acta Chem. Scand. 17, 1034 (1963); D. Vorländer, Ber. Deut. Chem. Ges. 64, 1736 (1931). 
${ }^{37}$ R. W. G. Wyckoff and R. B. Corey, Am. J. Sci. 218, 437 (1929).

${ }^{38}$ D. T. Cromer and R. J. Kline, J. Am. Chem. Soc. 76,5282 (1954).

${ }^{39}$ E. Staritzky and J. Singer, Acta Crystallogr. 5, 536 (1952).

${ }^{40} \mathrm{R}$. W. Berg (unpublished work).

${ }^{41} \mathrm{H}$. Poulet and J. P. Mathieu, Spectres de Vibration et Symétrie des Cristaux (Gordon and Breach, Paris, 1970).

${ }^{42}$ R. Schaeffer, Q. Johnson, and G. S. Smith, Inorg. Chem. 4, 917 (1965).

${ }^{43}$ M. Stammler, J. Inorg. Nucl. Chem. 29, 2203 (1967); G. L. Bottger and A. L. Geddes, Spectrochim. Acta 21, 1701 (1965), and references therein.

${ }^{44}$ W. J. McLean and G. A. Jeffrey, J. Chem. Phys. 49, 4556 (1968).

${ }^{45} \mathrm{~J}$. W. Lauher and J. A. Ibers, Inorg. Chem. 14, 1348 (1975).

${ }^{46}$ M. Cowie and M. J. Bennet, Inorg. Chem. 15, 1595 (1976).
${ }^{47}$ J. D. McCullough, Acta Crystallogr. 17, 1067 (1964).

${ }^{48}$ G. D. Stucky, Acta Crystallogr. B 24, 330 (1968); P. S. Peercy, B. Morosin, and G. A. Samara, Phys. Rev. B 8, 3378 (1973); and references therein.

${ }^{49}$ E. I. Toplin and W. N. Lipscomb, Inorg. Chem. 12, 2257 (1973).

${ }^{50}$ R. B. Corey, Z, Kristallogr. 89, 10 (1934).

${ }^{51}$ V. A. Gerken, V. I. Pakhomov, A. S. Sonin, E. I. Marchenko, and N. Nepomnyashchaya, Sov. Phys. -C rystallogr. 12, 531 (1968).

${ }^{52}$ S. Silver, J. Chem. Phys. 8, $919(1940)$.

${ }^{53}$ D. S. Kendall and W. N. Lipscomb, Inorg. Chem. 12, 546 (1973).

${ }^{54} \mathrm{~F}$. Hanic, Chem. Zvesti 20, 738 (1966); Chem. Abstr. 66, 89253t (1967).

${ }^{55}$ M. A. Hepworth, P. L. Robinson, and G. J. Westland, J. Chem. Soc. 1958,611 . 